\title{
On the Development of Spart (sports art)-A Proposed Method
}

ISSN: 2577-1914

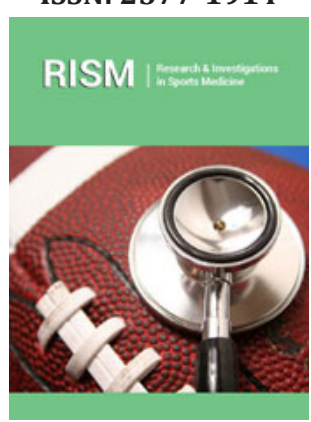

*Corresponding author: Daniel Shorkend, Wizo School of Design, Isreal

Submission: 制 September 26, 2019

Published: 非October 21, 2019

Volume 5 - Issue 4

How to cite this article: Daniel Shorkend On the Development of Spart (sports art)-A Proposed Method. Res Inves Sports Med. 5(4). RISM.000616.2019.

DOI: 10.31031/RISM.2019.05.000616

Copyright@ Daniel Shorkend, This article is distributed under the terms of the Creative Commons Attribution 4.0 International License, which permits unrestricted use and redistribution provided that the original author and source are credited.

\section{Daniel Shorkend*}

Wizo School of Design, Isreal

\section{Opinion}

I would like to develop the dialectic between art and sport. My research thus far has indicated that indeed an overlap exists on many levels in terms of their shared aesthetic dimension. While this can be developed further and is rather intuitive being derived from the humanistic sciences, I wish to tackle the art-sport link from a robust scientific perspective and methodology.

My focus then is to determine a similar physiological and neurological wiring concerning both these disciplines. This may be due to the necessity that both are creative activities. The value of creativity can be defined as "...the introduction of something innovatively new and positive for society that goes beyond the familiar and accepted" (Zaidel, 2003). Furthermore, this can be seen to have been derived "...in humans...as an extension of the fundamental biological survival functions of cunning and deception" (Zaidel, 2003). Having said this and notwithstanding the fact that creativity is a topic of interest in recent years, it is at its early stages insofar as the understanding of the neural underpinning of creativity is concerned.

What is known is that common to creative ingenuity is at least moderate intelligence (Sternberg and Ohara, Rreader, Lefebvre et al. 2013 [1]), brain size in innovative animals (Reader and Lalend, Lefenvre), neurotransmitters Manzano et al. 2010 [2], ecological niches [1] and personality attributes (Gardner, Mithen). Furthermore, that creativity in the arts is not restricted to one hemisphere, but is diffusely represented (Rose, Bogousslasky and Boller, Zaidel [3-9] Finger, Mazzucchi et al. 2013 [10], Piechowski, Jozwiak and Bogousslavsky). Other factors such as structural anomalies necessary for human creativity and risk-taking were also found to be common features of artistic creativity. In a study by De Pisapia, Bacci, Parrot and Melcher, it was found that both divergent (DMN) and convergent (EN) thinking processes worked together for optimal artistic creativity - processes often thought to be in opposition. Zeki (2001), moreover argued that artists "...are in a sense neurologists who unknowingly study the brain with techniques unique to them", by which he meant that the ability of outstanding artists to seek knowledge of the world and abstract essentials parallel laws of the visual brain, where for example, the straight line could be seen as the building blocks of form perception (think here of Mondrian or Newman) or Calder and Tiguely in their emphasis of motion over form and colour that relates to the visual motion centre of the brain (V5). What all this points to is that the brain functions in a particular way and with specific attributes in order to unleash artistic creativity. The question is: How can we improve the neural networks to enhance creativity, artistic or otherwise?

Rather than seek ways to answer that question, which is quite broad, let us for a moment consider sport. We tend to think that excellence in sport is determined by physical prowess alone in terms of size, speed and strength but this is changing with the acknowledgement of the massive impact of the brain in athletic performance. Researchers are recognising "athletic intelligence as a measurable and perhaps predictable trait" [11]. Sports and games offer a certain complexity in which to exercise human creativity. Research has shown, furthermore that sport requires imagination and that simply walking enhances the minds capacities through heightened mind-body dynamics. Noakes 2010 [12] argues for the "central governance hypothesis" wherein apparent fatigue obfuscates the fact that there is still much energy in reserve, thus implicating mental processes that may override what only appears 
to be a physical limit. Elite sportsman has an uncanny ability to intuit where a play may lead and where to so position oneself. It has, furthermore, been shown with EEG precision that elite athletes decide more quickly and accurately when to, say swing a bat (as in say baseball) and when to desist.

Thus, the question is: What levels of mental activity are beneficial or detrimental to physical performance? Understanding the brain mechanism of this will require cognitive neuroscience to develop methods and models that can assess brain activity in real time under conditions of stress and activity. My intuitive answer and new contribution to that question and based on my findings on the aesthetic overlap between art and sport, is that art is particularly well appointed to enhance sports performance. I would like to research this scientifically to test that link in more robust, quantitated scientific terms. I intend to do so in terms of the following methodology or series of experiments:

1. I propose to facilitate art-classes among an experimental group of competitive sportspersons - all other variables remaining equal - and determining after a 10 week, once a week, two-hour course - whether a measurable improvement in their sports performance took place following the course as opposed to a control group - all other variables being equal - that are not exposed to the art training. My course is called "ignite insight" and consists of specifically designed methods and visual aids that relate art-making to their chosen sport.

2. I also wish to measure whether similar brain states and patterns exist among artists when a) engaged in art and b) after completion of an artwork. I intent to do this by taking 20 professional artists that volunteer to undergo fmri scanning as well as EEG scanning a) while engaged with an art-task and b) having been "satiated" - after completion of the art task.

3. I also wish to measure whether similar brain states and patterns exist among sportspersons (taken from experimental group 1) when a) watching their favourite sport and b) after physically engaging in their favourite sport having now reached "satiation". During "phase" a) and b), fmri and EEG scanning will occur.

I now will compare the results of 2 and 3 and assess whether artists and athletes exhibit similar structural and other patterns in the brain that thus point to the shared neural commonalities of creativity in both art and sport.

If indeed in can be shown that a) engaging in art improves sports performance and b) neurologically there is a similar mechanism in the brain in place that occurs in optimal artistic and sporting performance, then the basis for Spart or sports art exists. This, then is a new and pioneering field (perhaps adjoined to sports science). It points also to an alternative method of coaching with the potential to enhance sports performance and understanding creativity, play and training on a deeper level. Philosophically, it also points to what I dub an "epistemological unity" and interdisciplinary nexus wherein the sciences and the humanities coalesce.

\section{References}

1. Lefebvre L, Reader S, Sol D (2013) Innovating innovation rate and its relationship with brains, ecology and general intelligence. Brain Behav Evol 81(3): 143-145.

2. Mazono D, Cervenka S, Karabanov A, Farde L, Ullsssn F (2010) Thinking outside a less intact box: Thalamic dopamine D2 receptor densities are negatively related to psychometric creativity in healthy individuals. PlosOne https://doi.org/10.1371/journal.pone.0010670.

3. Zaidel DW (2005) Neuropsychology of art: Neurological cognitive perspectives. Psychology press, UK.

4. Zaidel DW (2010) Art and Brain: Insights from neuropsychology, biology and evolution. J Anat 216(2): 177-183.

5. Zaidel DW (2014) Creativity, brain and art: biological and neurological considerations. Front Hum Neurosci 8: 389.

6. Zaidel DW (2013) Art and brain: The relationship of biology and evolution in art. Prog Brain Res 204: 217-233.

7. Zaidel DW (2013) Biological and neuronal underpinning of creativity. In: Vartaniana 0, et al. (Eds.), MIT press, Cambridge, UK, pp. 133-148.

8. Zaidel DW (2013) Cognition and art: The current interdisciplinary approach. Wiley Interdiscip Res Cog Sciff 4(4): 431-439.

9. Zaidel DW (2013) Split-brain: The right hemisphere and art-fact and fiction. Prog Brian Res 204: 3-17.

10. Mazzucchi A, Sinforiani E, Boller F (2013) Focal cerebral lesions and painting abilities. Prog Brain Res 204: 71-98.

11. Schonbrun Z (2017) Keep your eye on the ball. New York Times article, Jan $4^{\text {th }}, 2017$.

12. Noakes T (2007) Central governance hypothesis. Sports Med 37(4-5): 374-377.

For possible submissions Click below:

Submit Article 